\title{
Identity and Attributes of Āyurvedic Medicinal Plant Brāhmi/Aindri from Antiquity to the Modern Age
}

\author{
Ram H Singh*
}

(Received 04 May 2015; revised 30 May 2015)

\begin{abstract}
Brāhmi-Aindri Bacopa monnieri Linn of Scrophulariacea family is the most reputed medicinal plant of India traditionally known to possess memory and cognitive ability enhancing effect. The recent scientific studies have validated the 3000 years old traditional claims. But there are significant discrepancies in the textual versus botanical identities of this herb. Critical study of the ancient texts exhibit three classical plant names viz. brāhmi, mandukaparñ $\overline{\text { and }}$ aindri. The former two are supposedly synonym names, one indicative of cognitive function effect and the other indicative of the morphology of the plant itself which is identifiable with the plant Centella asiatica Linn. The third name (aindri) is a separate plant identifiable with Bacopa monnieri Linn. Thus there is significantly conflicting textual versus botanical identity of brähmi. However both these plants have similar medicinal effect. The recent clinical trials published by Con Stough and his team from Australia has lend significant credence to the traditional claims of memory enhancing and improving cognitive function by Bacopa monnieri (Stough, Lloyd, Clarke, et al , 2001, pp. 481-484; Stough, Downey, Lloyd, et al, 2008, pp. 1629-1634).

Bacopa monnieri contains Bacocides A and B and has potent memory and cognitive ability enhancer effect. There are rich experimental studies validating this attribute. Mode of action of the plant is still precisely not known. Studies are suggestive of multiple mechanisms of action largely simulating the medhya rasāyana effect as conceived in Āyurveda. The clinical trials are only few warranting further extended studies on the action potential of this important medicinal plant, more in human subjects before it is accepted as a proven medicine.
\end{abstract}

Key words: Aindri, Bacocides, Bacopa monnieri, Brāhmi, Mandukaparṇ̄, Medhya, Memory Enhancers, Rasāyana.

\section{INTRODUCTION}

Âyurveda is the oldest science of life, health care and cure in the world, its antiquity going back to the Vedas. The ancient knowledgebase is carried down the ages till today in the form of three pre-Christian classics namely Caraka, Suśruta and Vägbhata and three medieval texts namely, Mādhava Nidāna, Śāraingādhar Saṃhitā and Bhāva Prakāśa.

$\bar{A} y u r v e d a$ has its own fundamental principles, its unique biology, pathology, diagnostics and materia medica featured by a large number of herbomineral formulations with vivid description of few thousands of medicinal plants in professional therapeutic use warranting new scientific studies in order to bring them in to the main stream medicare. Brāhmi-Aindri is one among many such potential medicinal plants. Âyurveda describes a set of plant drugs called medhya rasāyanas which are claimed to be neuronutrients with anti-stress and memory enhancer effect. Brāhmi falls into this category. Botanical identification of brāhmi had continued

\footnotetext{
* Distinguished Professor, Department of Kāyācikitsa, Institute of Medical Sciences, Banaras Hindu University, Varanasi, India, Email: rh_singh2001@yahoo.com
} 
to be in controversy since long, though now the plant Bacopa monnieri is largely identified as brāhmi (bacopa) and is in popular use. A wide range of formulations and products containing brāhmi are already in the market popularly used by Ayurvedic practitioners.

The systematic scientific studies to ascertain and assess the efficacy of Brāhmi started in late $20^{\text {th }}$ century. One of the early studies which reported memory enhancing and anxiolytic effect in Brāhmi-Aindri Bacopa monnieri) was reported by Singh and Singh (1978-79) in the form of a Doctoral dissertation and few research publications in an Indian Journal (Singh, 2007, pp. 15-16 and Singh \& Singh, 1980, pp. 133-148). Subsequently many studies were initiated in different institutions, among which the prominent ones were the work of Dhawan and Singh (1982, pp. 205-214; 1997, pp.359-365; Singh, Rastogi, Srimal, Dhawan, 1988, pp.70-75). But because of lack of really a robust clinical evaluation this important plant based drug could not be brought into the realm of real evidence based medication and further studies are in progress (Rastogi, Chappelli, Ramchandani and Singh, 2012, pp. 1252).

\section{The Historical Account}

Bacopa monnieri Linn synonym Herpestis monnieri Linn, Vernacular name Brāhmi/Andri, family Scrophulariacae is a perennial herb found throughout India in marshy regions. Brāhmi is mentioned frequently in religious, social and medical treatises of ancient and medieval India since the Vedic era. The most organized descriptions are available in Āyurvedic classics and in the Nighantu texts with vivid description of its therapeutic use specially its attributes in treatment of mental disorders. As such Brāhmi is an extremely important medicinal plant of $\bar{A} y u r v e d a$, also described with certain other synonym names, some times becoming a problem in its textual identity.
Brāhmi is one of the most popularly used plant names in Ayurvedic herbal kingdom which refers to a very important drug plant of Ayurveda. In traditional style of herbal descriptions the Âyurvedic texts provide several synonyms of each plant, sometimes with overlapping usage. In the present context it is pertinent to refer to three overlapping names viz. brāhmi, mandukaparṇ̄ and aindri to throw light on the controversy about the authentic Samskrit name of the this drug plant.

Caraka the foremost classical authority on Āyurveda mentions brāhmi along with aindri among the prajasthapana group of drugs and again with mandukaparn̄i in the vayasthapana group of drugs. The same has been repeated in the context of garbhasthāpan group of drugs. Mandukaparñ̄ has been mentioned in the Tiktaskandha. In rasāyana chapter mandukaparñ $\bar{\imath}$ has been mentioned as medhya rasāyana with priority while brāhmi has not been mentioned as medhya rasāyana. Even in the formulation of brahma rasāyana only mandukaparn̄i is mentioned, not brāhmi. But in aindra rasāyana only brāhmi is mentioned and mandukaparn̄i has not been mentioned. Similarly in the treatment of Apasmāra (ie seizure disorder) brāhmi has been indicated, not mandukaparṇī. Mandukaparṇī has been included in sāka varga (vegetable category) but brāhmi has not been mentioned. Brāhmi has been mentioned in the treatment of kuștha (ie leprosy) while mandukaparn̄i is mentioned in the treatment of ksataksina disease (Pthisis). Similar trend is seen in Suśruta saṃhitā too. The Saṃhitās of Vāgbhața mention brāhmi in medhya formulations for treatment of apasmāra, kuștha and among rasāyana remedies while mandukaparñ̄ is mentioned among sāka varga ie edible vegetables and among the rasāyana remedies. Thus the descriptions of brāhmi and mandukaparn̄i in Samhitas are suggestive of following contention:

1. Brāhmi and Mandukaparṇ̄ have not been mentioned together in any context. 
2. Although mandukaparñ̄ is the prime medhya rasāyana drug but it has not been mentioned in the treatment of mental and seizure disorders.

3. Mandukaparn̄ī is described with prominence in Sāka varga

4. Some of the uses of brāhmi and mandukaparṇ̄ are common viz. kuṣtha.

From the above mentioned literary account it seems that brāhmi and mandukaparṇ̄ are synonym names of the same plant. Brāhmi is pharmacological name while mandukaparñi is a morphologic name of the same plant. Dalhana, the commentator of Suśruta Samhitā consistently considers brāhmi and mandukaparṇ̄ as one. In certain contexts another plant name lavanika has been used. The Nighaṇtu texts too seem to consider brāhmi and mandukaparṇī as synonyms. However same degree of controversy seems to prevail on this issue but in modern times mandukaparñi is used as brāhmi. In the efforts to reach the botanical identity of these plants the consensus grew in the past erroneously to take two different plants for these classical names viz.

1. Mandukaparṇ̄ as Centella asiatica Linn. Urban.

2. Brāhmi as Bacopa monnieri Linn. Pennell.

According to Sharma PV the main reason for the prevailing controversy seems to be the ignorance of the scholars about the identity of the third and the most important plant name aindri. It is pertinent to note that brāhmi and aindri have been mentioned together in the texts in single places indicating that they are two different entities. Some contexts are as below:

1. Prajāsthapana varga (Fertility promoters) $C$. S. Sū 4.

2. Garbhasthāpana varga (Sustainers of pregnancy) C.S. $S \bar{a} 8$

3. Aindra rasāyana (special formulation promoting cognition) C.S. Ci. 1.3

\section{Divyousadhi (divine medicines) C. S. Ci. 1/4}

This indicates that brāhmi and aindri are classically two different plants with similar actions (Agrawal and Singh, 1998, pp.97-107; Singh, Singh, Sen, 1979, pp 1-6; Singh, Sinha, 1979, pp.7-14; Singh, Narsimhamurthy, Singh, 2008, pp.369-374). Thus on the basis of classical descriptions it is imperative to conclude that brāhmi and mandukaparṇi are synonymous .They are not two different botanicals. Brāhmi is the activity name while mandukaparñ̄ is the morphological name of the same plant. And these should be identified with the botanical plant Centella asiatica Linn Urban. On the other hand aindri and indraballi are synonym for another plant and they should be taken as Bacopa monnieri Linn. Pennel. The same is Dalhana's lavanika. This is the classical textual account of three plant entities. It seems, because of the lack of classical knowledge and dichotomy between the Śāstra and the Science the controversy about the classical nomenclature of these medicinal plants continued. It is irreversible literary loss to note that most of the contemporary scientific publications use the word brāhmi for Bacopa monnieri ignoring the name aindri. This is literally incorrect (Caraka Saṃitā, edited by Sharma).

\section{The Concept of Rasāyana Remedies}

Since ancient times Āyurveda is practiced through its eight specialty branches. One of these eight specialties is called rasāyana tantra which deals with micronutrition, immunology, geriatrics and rejuvenation. Rasāyana tantra advocates rejuvenative life style, healthy dietetics and a range of herbomineral remedies which are claimed to supplement nourishing medicinal foods, enhance immunity and promote memory and cognitive functions. These vitalizing medicines improve the body-mind health by way of influencing the body through enriching the nutritional value of plasma as a direct nutrient and by metabolic boosting and by augmenting the process of microcirculation and 
tissue perfusion. Besides the nonspecific generic action some of these rasāyanas are tissue and organ specific such as medhya rasāyana for brain, hrdya rasāyana for health of heart, tvachya rasāyana for skin, cakșusya rasāyana for eyes, brisya rasāyana for virility and so on (Rastogi, 2014; Singh, Narsimhamurthy, Singh, 2008, 369374; Singh and Rastogi, 2012, pp. 177-190).

The medhya category of rasāyanas comprise of a large number of herbal plants and herbomineral compound formulations which are profusely used by Āyurvedic practitioners for treatment of a range of mental disorders such as anxiety states, stress disorders, seizure disorders, dementias and neuro-degenerative conditions. As these remedies are basically molecular nutrients they produce varying degree of neuroprotective, neuro-regenerative, anxiolytic, anti-stress, memory enhancer \& immunomodulator effect. Brāhmi/mandukaparṇi and andri are the most important members of medhya rasāyana group of drugs. In recent years there has been resurgence of interest in Ayurveda in general and its rasāyana tantra in particular because of its unique principles featured by pronature holistic and personalized treatment approach besides its rich cost-effective and safe green pharmacy. In recent years lot of research activities have been initiated in this field both from fundamental point of view and applied aspects including medicinal plants (Rastogi, 1990, pp.118-122; Satyavati, Raina, Sharma, 1976, pp. 112-118).

\section{BACOPA MONNIERI}

The plants Bacopa monnieri and Centella asiatica which represent brähmilandri and mandukaparṇ̄ are perennial herbs growing wild in marshy areas throughout India, Sri Lanka, China, Pakistan, Taiwan, Vietnam and Florida (Barrett, Strother, 1978, pp.408-419; Chopra, Nayar, Chopra,1956; Chunekar, 1960; Con Kerry and Andrew, 2013). Both these plants are popularly known to be of medicinal value especially for mental healthcare. Centella asiatica is also used as edible vegetable by some sections of the society while Bacopa being bitter in taste has no such usage. Rastogi et al (1996) reported a significant seasonal variation in the Bacoside concentration in Bacopa monnieri. Serial month wise collected fresh samples of this plant when studied chemically in relation to the five seasons of India revealed that Bacoside A and B were available in May while in rest of the months other compounds start appearing and disappearing.

The best characterized compounds in Bacopa are Dammarane-Type Triterpenoid Saponins known as Bacocides, with Jujubogmin or Pseudo jujubogmin moities as aglycone units. Bacocides comprise a family of dozen known analogs. Other Saponins called Bacopasides I-XII have been identified more recently. The Alkaloids Brahmine, nicotine and herpestisine have been catalogued, along with D-mannitol, apigenin, Hersaponin, Cucurbitacin and Plantainoside-B.

The most studied constituent has been Bacocide-A, which was found to be a blend of Bacocide $\mathrm{A}_{3}$, Bacopacide II, Bacopasaponin C. The concentration of these constituents in the plant is variable (Basu, Rastogi, Dhar, 1967, p 84; Chakravarty, Garai, Masuca, Nakane, Kawahara, 2003, pp.215-217; Chakravarty, Sarkar, Masuda, Shiojima, Nakane, Kawahara, 2001 Chakravarty, Sarkar, Nakane, Kawahara, Masuca, 2002; Chandel, Kulshreshtha, Rastogi, Bacogenin,1977, Channa, Dar, Yaqoob, Anjum, Sultani, Rahman, 2003; Duley, . Singh, Preethi and Rajan, 2012).

Pharmacologically Bacopa monnieri was shown to be antioxidant in vitro. It inhibits Acetylcholinesterase, activates Choline acetyltransferase and increases cerebral blood flow in rats. Studies have been reported to suggest protective effect in animal models of Neurodegeneration. Clinical studies have shown improvement on cognitive function and memory enhancing in human subjects (Aithal, Sirsi, 1961, 
pp,2-5; Dar, Channa, 1999, pp. 167-174; Dhawan, Singh, 1996, pp.144-149; Dhyanasekaran, Tharakan, Holcomb, et al, 2007, pp.965-969; Hota, Barhwal, Baitharu, Prasad, Singh, Ilavazhagan, 2009, pp. 23-39; Jain, Khanna, Trehan, Pendse., Godhwani, 1994, pp.633-636; Stough, et al, 2001, pp.481-484; Stough, Downey, Lloyd, et al., 2008, pp. 1629-1634).

Common adverse effects are nausea, griping, and GIT upset and in animal models it was shown to affect spermatogenesis. However, no such effect has been reported from the many clinical trials on human beings.

\section{The Major Action Profile}

In classical terms the Āyurvedic name for Bacopa should have been aindri, not brāhmi. However in view of the popular connotation for the purpose of this review the author shall here after use the word brāhmi-aindri because most of the recent scientific studies as published erroneously use the name brāhmi, not aindri. However the science activists have correctly taken the lead from the ancient tradition and have pursued scientific activities to validate the medhya effect and its possible mechanism of action and the same will be briefly reviewed in this article but they have ignored the correct classical name. However the emphasis of this write up is more on the review of efficacy studies not so much mechanism studies.

The clinical term medhya denotes "beneficial to medha "i.e. cognitive ability. Most of the studies conducted on this plant drug swing around its effect on cognitive ability and memory enhancing effect besides anxiolytic and anti-stress effect. Singh and Singh (1978) reported positive effect of Bacopa on immediate memory span, mental fatigue rate and on anxiety levels in cases of anxiety neurosis(Singh, 2001, 2003, 2007; Singh and Singh, 1980, pp. 133-148; Singh, Singh, Sen,1979, pp.1-6; Singh, Sinha, et al, 1979, pp.714). Naila Sheikh et al (2007) studied the impact of this drug on stress induced changes in plasma corticosterone and brain monoamines in rats. They also reported the adaptogenic effect in standardized extract of Bacopa in various models, showing the effect of this drug on brain amine levels in the cortex and hippocampus region of brain in rats, comparing the effect with Panax root power subjecting the animals to acute stress (Immobilization $\times 150$ minutes once a day) and chronic unpredictable stress (different stressors for 7 days) resulting in significant rise is plasma corticosterone levels which was significantly counter acted by the test drugs. Earlier Amitadas et al (2002) conducted a comparative study of the standardized extract of Bacopa monnieri and Ginkgo biloa in rodents showing anticholinesterase and cognitive enhancing activities (Das, Shankar, Nath, Pal, Singh, Singh, 2002, pp. 893-900; Maher, Stough, Shelmerdine, Wesnes, Nathan, 2002, pp. 163-164). Singh et al (2008) reviewed the clinical and experimental studies on several medhya rasāyana plant drugs of Ayurveda including brāhmi, mandukaparṇi and aśvagandhā suggesting similar neuronutrient and neuroprotective effect in medhya category of plants (Singh, Narsimhamurthy, Singh, 2008, pp. 369-374).

Jayaprakash et al (2014) also reported similar findings. Kobayama et al (2005) reported neuro-regenerartive effect of aśvagandha in his in-vitro studies demonstrating that when the neurons were cultured in vitro with WithanolideA the dendrites of neurons became elongated and the synopses got reconstructed. The induced Beta amyloid plaques were noticed to be dissolved. A several studies have been reported suggesting the beneficial effect of Bacopa monniera in allied diseases like Alzhemeir disease, anxiety neurosis and depression (Bhattacharya, Kumar, Ghosal, 1999, pp. 111-112; Bhattacharya, Kumar, Ghosal, 2000, pp. 174-179; Bhattacharya, Ghosal, 1998, pp. 77-82; Calabrese, Gregory, Leo, et al. 2008, 
707-713; Jyoti, Sharma, 2006,pp. 451-457; Uabundit, Wattanthorn, Mucimapura, Ingkaninan, 2010, pp.26-31).

Russo and Barrolli (2005) in their review on Bacopa monnieri observed that the plant drug Bacopa does possess significant nootropic effect as well as anti-inflammatory and cardiotonic effect warranting extended clinical evaluation for safety and efficacy in human settings. Con Stough et al (2013) in their systematic review noticed eight human randomized controlled trials that met entry requirements ie double blinded high quality studies of which seven used a single $300 \mathrm{mg}$ dose. No acute studies have yet shown a positive cognitive enhancement although there are some trials underway. These reviewers postulated that Bacopa monnieri is likely to exert cognitive enhancement through inflammatory, antioxidant or even removal of beta amyloid besides via blood flow or direct neurotransmitters. The exact mechanism is yet to be determined. This quality review concludes "High quality extracts of Bacopa monnieri appear highly promising for chronic treatment of age related cognitive decline. Bacopa monnieri extract may have multiple mechanisms of action on central nervous system such as antiinflammatory, antioxidant, Beta amyloid cleansing besides improved cardiovascular functioning and increased dendrite connectivity (Holcomb, Dhanasekaran, Hitt, et al., 2006, pp.243-251; Limpeancholo, Jaipan, Rattanakaruna, et al., 2008, pp.112-117). Singh HK (2013) extensively reviewing his own studies on memory enhancing and associated effects of a Bacocides-enriched standardized extract of Bacopa monnieri suggests that Bacopa is a safe and moderately effective plant based medicine with significant memory enhancing, anxiolytic, learning promoting and neuroprotective effect(Singh, 2013, pp. 251-288).

Mathew et al (2012) reviewed the studies on cognitive-enhancing effects of Bacopa monnieri and the related clinical trials. The review admits that traditional knowledge-base is suggestive of the fact that Bacopa enhances cognitive performance. Such traditional accounts have now been successfully tested through few randomized controlled clinical trials which were subjected to systematic review by Mathew et al 2012 with a view to examine the strength of scientific evidence as to whether Bacopa really enhances cognitive performance in human subjects. This review concludes that Bacopa monnieri improves memory free recall with evidence for enhancement in other cognitive abilities. The reviewers point out that research into nootropic effects of Bacopa is still in infancy.

Jayakumar et al 2012, 2014 investigated the process of participation of microRNA 124CREB pathway - a parallel memory enhancing mechanism of standardized extract of Bacopa. Bacocide, the effective component of standardized extract has been reported to have memory enhancing effect. Jayakumar and Singh (2014) reported that standardized extract of Bacopa monnieri improves contextual fear memory by differentially regulating the activity of Histone Acetylation and protein phosphatases in hippocampus (Jayakumar, Hemant, Singh, Jois, Koilmani, 2014).

Charles P Duley et al 2012 observed that extract of Bacopa attenuates contextual associative learning deficits in aging rats brain induced by DGalactose indicating neuroprotective impact in Bacopa extract (Dulcy, Singh, Preethi, Rajan, 2012, pp. 2053-2064; Emmanuval, Singh, Parkavi, Prisila, 2011, pp. 2136-2144).

\section{Conclusion}

There is significantly conflicting textual versus botanical identity of Brāhmi and Aindri identifiable with Centella asiatica and Bacopa monnieri respectively. However, both these plants are similar in action. Both are memory and cognitive ability enhancers. In traditional clinical practice often they are used interchangeably. It will be useful to launch comparative studies on these 
two plants which may show different mechanisms of similar action. Obviously Bacopa monnieri has already been studied extensively and now there is considerable new scientific evidence to suggest its memory enhancer effect which validates the thousands of years old traditional textual and experience-based claims. Inspite of many laboratory studies the actual mechanism of action of Bacopa monnieri is still not clearly known. Studies suggest the possibility of multiple mechanisms of action ranging from antioxidant, inflammatory, haemodynamic, direct neurotransmitteral and increasd dendrites connectivity besides neuro-regenerative, neuronutrient and nonspecific neuroprotective effect conforming with the Rasāyana approach of Âyurveda.

This review is on two important medicinal plants which have been traditionally used in Āyurveda as "medhya rasāyana" for improvement of cognitive and related functions of the brain. As regards the identity of the plants this systematic review concludes as below.

1. Brāhmi and Aindri are two different plants with similar action.

2. Brāhmi and Madhukaparṇ̄̄ are synonymous and can be identified with Centella asiatica Linn. Urban.

3. Aindri and Indrahalli are synonymous and can be identified with Bacopa monnieri Linn. Pennell.

4. Brāhmi cannot be identified with Bacopa monnieri Linn. Pennel.

5. The experimental and clinical effects of both the above mentioned plants are similar on cognitive ability, reduction of anxiety level, mental fatigue etc.

\section{BiBLIOGRAPHY}

Agrawal, S C, Singh, R H. Effect of Medhya Rasāyana drug, Mandukaparṇ̄ (Centella asiatica) on cognitive functions and social adaptability in mental retardation. J Res Ayu Siddha. 1998.18(3-4):97-107.

Aithal, H N, Sirsi, M, Pharmacological investigation on Herpestis monniera. Ind J Pharmacol 23: (1961) 2-5.

Barrett, S C H, Strother, J L. Taxonomy and natural history of Bacopa in California. Syst. Bot. 5(1978):408-419.

Basu, N, Rastogi, R P, Dhar, M L. Chemical examination of Bacopa monniera Wettst part III: the constitution of bacoside-B. Indian J Chem., 5(1967):84.

Bhattacharya, S K, Kumar, A., Ghosal, S. Effect of Bacopa monniera on animal models of Alzheimer's disease and perturbed central cholinergic markers of cognition in rats. Res Commun Pharmacol Toxicol 4(1999):111112.

Bhattacharya, S K, Kumar, A, Ghosal, S. Antioxidant activity of Bacopa monniera in rat frontal cortex, striatum and hippocampus. Phytother Res; 14(2000): 174-179.

Bhattacharya, S K, Ghosal, S. Anxiolytic activity of a standardized extract of Bacopa monniera: an experimental study, Phytomedicine; 5 (1998)77-82.

Calabrese, C, Gregory, W L, Leo, M, et al. Effects of a standardized Bacopa monnieri extract on cognitive performance, anxiety and depression in the elderly: A randomized, double-blind, placebo-controlled trial. $J$ Altern Complement Med; 14(2008):707-713.

Caraka, Caraka Saṃhitā 600BC Edited by Sharma, PV, Choukhamba Orientalia, Varanasi/Delhi, India.

Chakravarty, A K, Garai, S, Masuca, K, Nakane, T, Kawahara, N. Bacopasides III-V, three new triterpenoid glycosides from Bacopa monniera. Chem Pharm Bull, 51(2003):215-217.

Chakravarty, A K, Sarkar, T, Masuda, K, Shiojima, K, Nakane, T, Kawahara, N. Bacopaside I and II two pseudojujubogenin glycosides from Bacopa monniera. Phytochemistry 58(2001): 553-556.

Chakravarty, A K, Sarkar, T, Nakane, T, Kawahara, N, Masuca, K. New phenylethanoid glycosides from Bacopa monniera. Chem Pharm Bull, 50(2002): 16161618.

Chandel, R S, Kulshreshtha, D K, Rastogi, R P, Bacogenin A: a new sapogenin from Bacopa monniera. Phytochemistry; 16(1977):141-143.

Channa, S, Dar, A, Yaqoob, M, Anjum, S, Sultani, Z, Rahman, A. Broncho-vasodilatatory activity of fractions and pure constituents isolated from Bacopa monniera. J. Ethnopharmacol; 86(2003):27-35. 
Charles, Prisila Duley, Singh, Hemant K., Preethi, Jayakumar and Rajan, Koilmani Emmanuvel. Standardized Extract of Bacopa monniera (BESEB CDRI-08) Attenuates Contestual Associative Learning Deficits in the Aging Rats's Brain Induced by DGalactose. Journal of Neuroscience Research, 90 (2012):2053-2064.

Chattarjee, N, Rastogi, R P, Dhar, M L, Chemical examination of Bacopa monniera Wettst: Part-I. Isolation of chemical constituents. Ind J Che 3(1963): 24-9.

Chatterji, N, Rastogi, R P, Dhar, M L. Chemical examination of Bacopa monniera Wettst: the constitution of bacoside A. Indian J Chem 3(1965): 24-29.

Chopra, R N, Nayar, L,Chopra, I C. Glossary of Indian Medicinal Plants, vol. 32. Council of Scientific and Industrial Research, New Delhi India,1956.

Chunekar, K C. Bhāv Prakāśa Nighanțu. Chaukhamba Publications, Varanasi, 1960.

Con, Kerry Kenneth Stough, Andrew, Scholey. Advances in Natural Medicines, Nutraceuticals and Neurocognition, CRC Press January 10, 2013.

Con, Stough, Vanessa, Cropley, Matthew, Pase, rew, Scholey, and James, Kean. Assessing the Utility of Bacopa monnieri to treat the Neurobiological and Cognitive Processes Underpinning Cognitive Aging. Chapter 12 Advances in Natural Medicines, Nutraceuticals and Neurocognition Edited by Con Kerry Kenneth Stough and Andrew Scholey, CRC Press, 2013 Pages 241250 .

Dar, A., Channa, S. Calcium antagonistic activity of of Bacopa monniera on vascular and intestinal smooth muscles of rabbit and guinea-pig. J. Ethnopharmacol., 66(1999):167-174.

Das, Amitava, Shankar, Girja, Nath, Chandishwar, Pal, Raghwendra, Singh, Satyawan, Singh, Hemant K. A comparative study in rodents of standardized extracts of Bacopa monnieri and Ginkgo biloba Anticholinesterase and cognitive enhancing activities. Pharmacology Biochemistry and Behavior 2002; 73: 893-900.

Das, A, Shankar, G, Nath, C, Pal, R, Singh, S, Singh, H. A comparative study in rodents of standardized extracts of Bacopa monniera and Ginkgo biloba. Pharmacology Biochemistry Behaviour, 73 (2002): 893-900.

Dhawan, B N, Singh, H K. Pharmacological studies on Bacopa monniera, an Ayurvedic nootropic agent.
European Journal of Neuropsychopharmacology, 653(1996):144-149.

Dhyanasekaran, M, Tharakan, B, Holcomb, L A, et al. Neuroprotective mechanisms of Ayurvedic antidementia botanical Bacopa monniera, Phytother Res; 21 (2007): 965-969.

Dulcy, C P, Singh, H K, Preethi, J, Rajan, K E. Standardized extract of Bacopa monniera (BESEB CDRI-08) Attenuates contextual associative learning deficits in the aging rat's Brain Induced by D-Galactose. Journal of Neuroscience Research, 90 (2012): 2053-2064.

Emmanuval, Rajan K, Singh, H K, Parkavi, A, Prisila, D C. Attenuation of 1-( $m$-chlorophenyl) biguanide induced hippocampus-dependent memmory impairment by a standardised extract of Bacopa monniera (BESEB CDRI-08). Neurochem Res 36 (2011): 2136-2144.

Holcomb, L A, Dhanasekaran, M, Hitt, A R, et al. Bacopa monniera extract reduces amyloid levels in PSAPP mice. J Aizheimer's Dis, 9 (2006): 243-251.

Hota, S K, Barhwal, K, Baitharu, I, Prasad, D, Singh, S B, Ilavazhagan, G. Bacopa monniera leaf extract ameliorates hypobaric hypoxia induced spatial memory impairment. Neurobiol Dis 34 (2009): 2339.

Jain, P, Khanna, N K, Trehan, T, Pendse, V K, Godhwani, J L. Antiinflammatory effects of an Ayurvedic preparation, Brahmi Rasayan, in rodents. Indian J. Exp. Biol., 32 (1994): 633-636.

Jayakumar, P, Hemant, K Singh, Jois, S V, Koilmani, E R. Standardized Extract of Bacopa monniera (CDRI-08) improves contextual fear memory by differentially regulating the activity of histone acetylation and protein phosphatases (PP1a, PP2A) in Hippocampus. Springer Science + Business Media, New York, 2014.

Jyoti, A, Sharma, D. Neuroprotective role of Bacopa monniera. extract against aluminium-induced oxidative stress in the hippocampus of rat brain. Neurotoxicology; 27 (2006): 451-457.

Limpeancholo, N, Jaipan, S, Rattanakaruna, S, et al. Neuroprotective effect of Bacopa monnieri on betaamyloid-induced cell death in primary cortical culture. J. Ethnopharmacol, 120 (2008): 112-117.

Maher, B F, Stough, C, Shelmerdine, A, Wesnes, K, Nathan, $\mathrm{P}$ J. The acute effects of combined administration of Ginkgo biloba and Bacopa monniera on cognitive function in humans. Hum. Psychopharmacol, 17 (2002): 163-164. 
Martis, G, Rao, A, Karanth, K S. Neuropharmaological activity of Herpestis monnirea. Fitoterapia, 63 (1992): 399-404.

Matthew, P P, Jams, K, Jerome, S, Chris, N, Andrew, B S, Con, S. The cognitive-enhancing effects of Bacopa monnieri: A systematic review of randomized, controlled human clinical trails. The Journal of Alternative and Complementary Medicine; 18.7 (2012): 647-652.

Morgan, A, Stevens, J. Does Bacopa monnieri improves memory performance in older persons? Results of a randomized, placebo-controlled, double-blind trial. $J$ Altern Complement Med; 16 (2010): 753-759.

Pase, Matthew P., Kean, James, Sarris, Jerome, Neale, Chris, Scholey, Andrew B, Stough, Con. The CognitiveEnhancing Effects of Bacopa monnieri: A Systematic Review of Randomized, Controlled Human Clinical Trials. Journal of Alternative \& Complementary Medicine; 18.7 (2012): 647.

Pathak, S R, Singh, R H. Study on influence of some plant products on brain function. Ph.D. Thesis (AyuZoology), Banaras Hindu University, Varanasi, 1986.

Preeth, J, Singh, H K, Charles, P D, Rajan, K E, Participaiton of micro RNA 124-CREB pathway: a parallel memory enhancing mechanism of standardized extract of Bacopa monniera (BESEB CDRI-08). Neurochem Res.; 37.10 (2012): 2167-2177.

Preethi, Jayakumar, Singh, Hemant, Venkataraman, Jois, Rajan, Koilmani. Standardised Extract of Bacopa monniera (CDRI-08) Improves Contextual Fear Memory by Differentially Regulating the Activity of Histone Acetylation and Protein Phosphatases (PP1 $\hat{\mathrm{I}} \pm$, PP2A) in Hippocampus. Cellular \& Molecular Neurobiology; 34.4 (2014): 577.

Raghav, S, Singh, H, Alal, P K, Srvastava, J S, Asthana, O P. Randomized controlled trial of standardized Bacopa monniera extract in age-associated memory impairment. Indian J Psychiatry, 48 (2006): 238-242.

Rai, D, Bhatia, G, Palit, G, Pal, R, Singh, S, Singh, H K. Adaptogenic effect of Bacopa monniera (Brāhmi). Pharmacology Biochemistry Behaviour; 75 (2003): 823-830.

Rasso, A, Izzo, A A, Borrelli, F, et al. Free radical scavenging capacity and protective effect of Bacopa monniera L. on DNA damage. Phytother Res; 17 (2003): 870-875.

Rastogi, R P. Compendium of Indian Medicinal Plants, vol.I. CSIR, New Delhi, 1990.
Rastogi, S, Chappelli, F, Ramchandani, M H and Singh, R H. Evidence-based practice in complementary and alternative medicine. Pub. Springer Germany, 2012.

Rastogi, S (Ed.) Ayurvedic science of food and nutrition. $1^{\text {st }}$ Edition. Springer, New York, 2014.

Rege, N N, Thatte, U M, Dahanukar, S A. Adaptogenic properties of six Rasāyanas herbs used in Āyurvedic medicine. Phytotherapy Research; 13 (1999): $275-$ 291.

Roodenrys, S, Booth, D, Bulzomi, S, et al. Chronic effect of Brāhmi (Bacopa monnieri) on human memory. Neuropsychopharmacology; 27 (2002): 279-281.

Russo, A, Borrelli, F. Bacopa monniera, a reputed nootropic plant: an overview. Phytomedicine, 2005; 12: 305-317.

Russo, A, Izzo, A A, Borrelli, F, Renis, M, Vanella, A, Free radical scavenging capacity and protective effect on DNA damage of Bacopa monniera L. Phytother. Res., 17 (2003): 870-875.

Sairam, K, Dorababu, M, Goel, R K, Bhatacharya, S K. Antidepressant activity of standardized extract of Bacopa monniera in experimental models of depression in rats. Phytomedicine; 9 (2002): 207-211.

Saraf, M K, Prabhakar, S, Anand, A. Neuroprotective effect of Bacopa monniera on ischemia induced brain injury. Pharmacol Biochem Behav; 97 (2010): 192-197.

Śāraṅgdhara (1300AD) Śārañgdhara Saṃhitā. Part-2/6. Choukhamba, Publications, Varanasi, India.

Satyavati, G V, Raina, M K, Sharma, M. Medicinal Plants of India, vol. I Indian Council of Medical Research, New Delhi, 1976.

Shanker, G, Singh, H K. Anxiolytic profile of standardized Brāhmi extract. Ind J Pharmacol; 32 (2000): 152.

Shanmugasundaram, E R, Akbar, G K, Shanmugasundaram K.R. Brāhmighrtham, an Ayurvedic herbal formula for the control of epilepsy. J. Ethnopharmacol.; 33 (1991): 269-276.

Sheikh, N, Ahmad, A, Siripurapu, K B, Kuchibhotla, V K, Singh, S, Palit, G. Effect of Bacopa monniera on stress induced changes in plasma corticosterone and brain monoamine in rats. J. Ehanoparmacol. 2007; III: 671676.

Sheikh, Naila, Ahmad, Ausaf, Siripurapu, Kiran, Babu, Kuchibhotla, Vijaya Kumar, Singh, Satyawan, Palit, Gautam. Effect of Bacopa monniera on stress induced changes in plasma corticosterone and brain monoamines in rats. Journal of Ethnopharmocology; 111 (2007): 671-676. 
Shukia, B, Khanna, N K, Godhwani, J L. Effect of Brāhmi Rasāyana on the central nervous system. $J$. Ethnopharmacol. 21 (1987): 65-74.

Singh, H K, Dhawan, B N, Effect of Bacopa monniera Linn. (Brāhmi) extract on avoidance responses in rats. $J$ Ethnopharmacol. 5 (1982): 205-214.

Singh, H K, Dhawan, B N. Neuropsychopharmacological effects of the ayurvedic nootropic Bacopa monniera Linn (Brahmi). Indian J Pharmacol; 29 (1997): 359-365.

Singh, H K, Rastogi, R P, Srimal, R C, Dhawan, B N. Effect of bacosides $\mathrm{A}$ and $\mathrm{B}$ on avoidance responses in rats. Phytother Res; 2 (1988): 70-75.

Singh, Hemant K. Memory-Enhancing and Associated Effects of a Bacosides-Enriched Standardized Extract of Bacopa monniera (BESEB-CDRI-08). Chapter 13 Advances in Natural Medicines, Nutraceuticals and Neurocognition Edited by Con Kerry Kenneth Stough and Andrew Scholey CRC Press 2013 Pages 251-288.

Singh, L, Singh, R H. Study on psychotropic effect of Brāhmi (Bacopa monnieri) M.D. Ay. Thesis, Banaras Hindu University, Varanasi, 1978.

Singh, R H. The holistic principles of Ayurvedic medicine. Choukhamba Surbharti, New Delhi, 2001.

Singh, R H. Psychiatric disorders in Āyurveda. In: Mishra LC (ed) Scientific basis of Āyurvedic therapies. CRC Press, Boca Raton, 2003.

Singh, R H. Brain Aging and Āyurveda-Special Reference to Rasāyana Therapy. Ann Neurosci; 14(Suppl.) (2007) 15-16.

Singh, R H and Singh, L. Studies on antianxiety effect of Medhya Rasāyana drug Brāhmi (Bacopa monnieri) Part II J. Res. Āurveda Sidha 1980; 1: 133-148

Singh, R H, Singh, L, Sen, S P. Antianxiety effect of Medhya Rasāyana drug Brāhmi (Bacopa monnieri) Part I. J Res Ind Med; 14.03 (1979): 01-06.
Singh, R H, Sinha, B N et al. Comparative biochemical studies on the effect of four Medhya Rasāyana drugs on brain in rats. J Res Ind Med; 14.03 (1979): 0714.

Singh, R H, Narsimhamurthy, K, Singh, Girish, Neuronutrient impact of Āyurvedic Rasāyana therapy in brain aging. Biogerontology; 9.6 (2008): 369374.

Singh, R H. The basic tenets of Ayurvedic dietetics and Nutrition, In Ayurvedic Science of food and nutrition (ed.) S. Rastogi .Springer New York, 2014.

Singh, R H and Rastogi, S. Rasayana therapy and rejuvenation PP177-190. In Evidence based practice of CAM, pub. Springer, Germany. 2012.

Stough, $\mathrm{C}$ et al. The chronic effect of Bacopa monnieri (Brāhmi) on cognitive functions on healthy human subjects. Psychopharmacology; 156.4 (2001): 481484.

Stough, C, Lloyd, J, Clarke, J et al. The chronic effects of an extract of Bacopa monniera (Brāhmi) on cognitive function in healthy human subjects. Psychopharmacology; 156 (2001): 481-484.

Stough, C, Downey, L A, Lloyd, J, et al. Examining the nootropic effects of a special extract of Bacopa monniera on human cognitive functioning: 90 day double-blind placebo-controlled randomized trial. Phytother Res; 22 (2008): 1629-1634.

Suśruta, Suśruta Saṃhita 500BC, edited by Sinhgal, GD et al, Choukhamba Surbharati, Varanasi/Delhi, India.

Uabundit, N, Wattanthorn, J, Mucimapura, S, Ingkaninan, $\mathrm{K}$. Cognitive enhancement and nuroprotective effects of Bacopa monnieri in Alzheimer's disease model. $J$ Ethnophamacol; 127(2010): 26-31.

Vāgbhaṭa (300 AD) Aștāñga Hṛdaya/Aștāinga Saṃgraha. Choukhamba publications Varanasi, India. 